\title{
Zoonotic Viruses as a Risk Factor for Tumor Growth Initiation
}

\author{
Andrei Alimov* \\ Research Centre for Medical Genetics, Russia
}

ISSN: 2578-0190

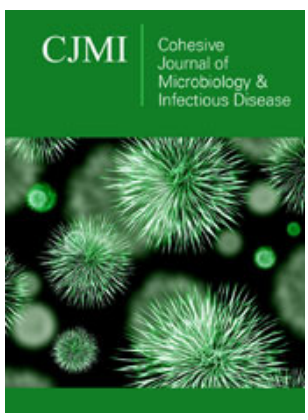

${ }^{* 1}$ Corresponding author: Andrei Alimov, Research Centre for Medical Genetics, 115478 Moscow, Moskvorechie str, 1, Russian Federation, Russia

Submission: 侮 June 25, 2019

Published: 㘹July 02, 2019

Volume 2 - Issue 5

How to cite this article: Andrei A. Zoonotic Viruses as a Risk Factor for Tumor Growth Initiation. Cohesive J Microbiol Infect Dis. 2(5). CJMI.000548.2019.

DOI: $10.31031 / C J M I .2019 .02 .000548$

Copyright@ Andrei Alimov, This article is distributed under the terms of the Creative Commons Attribution 4.0 International License, which permits unrestricted use and redistribution provided that the original author and source are credited.

\section{Editorial}

Numerous studies in the field of cancer biology prove that the development of any tumor goes through the stages of initiation, promotion and progression. The first genomedestabilizing event directs cells to the pathway of mutation accumulation, which ultimately leads to tumor development. Over the past decade, a large number of genome destabilizing factors were discovered. These include such as chemical mutagens, radiation, oncoviruses, insolation and the like. Animal viruses are among the least proven group of risk factors capable of initiating tumor growth. Skeptics argue that animal viruses do not penetrate the cells, and therefore do not initiate tumor growth [1]. Opponents of this statement give experimental data indicating the existence of more complex mechanisms of cancer initiation by zoonotic viruses.

Regular epidemiological observations indicate an increase in the number of cancer patients among food industry workers engaged in the primary processing of animal raw materials [2]. These studies are difficult to consider as a set of artifacts, since most of them were carried out on large samples in compliance with procedure of statistical data processing including control samples. In particular, long-term observations of poultry workers revealed higher incidence of lung cancer rather than in control sample. Sample size amount in this study is totals 30411 people. Based on the calculations, the authors suggested that the observed effect has a biological nature and requires molecular confirmation [3].

At the molecular level, Bovine leukemia virus (BLV) was actively examined as a risk factor for cancer initiation. The first studies revealed no link between the virus and human cancer. This conclusion was considered proven until the end of the last century, but later studies conducted at a new technical level, questioned the validity of these results. In particular, antibodies to the capsid protein p24 were found in the blood of volunteers. In an extended study, it was shown that antibodies of all four isotypes (IgG1, IgM, IgA, and IgG4) are able to circulate in human blood [4]. In our study, the presence of viral RNA was detected in several donor blood samples as a result of PCR screening conducted in 2012-2013. Recently, antibodies to the p24 capsid protein were found in blood samples from patients at Kaiser Permanente Hospital [5]. In addition, fragments of virus DNA were detected in the same samples. However, the question of whether the virus can initiate tumor development remains open.

Interesting data was collected by Brazilian colleagues [6]. It is found that the genomic copy of BLV can be detected in both the tumor tissue of the breast and in the healthy tissue of the mammary gland. However, in tumor samples, the virus was detected much more often. Based on those results authors suggested that BLV virus is associated with the development of breast cancer in humans [6].

The role of Mouse mammary tumor virus (MMTV) in the initiation of human breast cancer is also poorly understood [7]. Not all infected patients develop a tumor, which suggests the existence of a more complex mechanism of virus involvement in the initiation of tumor growth. It should be noted that the mouse MMTV and MMTV -like human virus are two different variants. Their genome coincides by $95 \%$. 
A new concept may be proposed to explain how animal viruses can penetrate human cells and initiate tumor growth. This was made possible by advanced analysis of somatic tissues using RNA sequencing recently published in Science [8]. In this study, high genetic heterogeneity of histologically unchanged somatic tissues was found. This suggests a spontaneous appearance of proteins on the outer surface of cell that can serve as an input to the virus. The appearance of viral entry as a result of somatic mutation can be considered as a risk factor for tumor growth initiation. This model assumes that the penetration of virus is sufficient to initiate tumor growth, but its subsequent functioning doesn't contribute to disease progression. Thus, zoogenic viruses have a chance to penetrate "cells of risks" due to certain mutations.

\section{References}

1. Schat KA, Erb HN (2014) Lack of evidence that avian oncogenic viruses are infectious for humans: A review. Avian Dis Sep 58(3): 345-58. DOI: 10.1637/10847-041514-Review.1

2. McLean D, Cheng S, 't Mannetje A, Woodward A, Pearce N (2004) Mortality and cancer incidence in New Zealand meat workers. Occup Environ Med 61(6): 541-547.
3. Johnson ES, Faramawi M, Chedjieu IP, Delongchamp R, Choi KM et al. (2018) Excess lung cancer occurrence in poultry plants. Occupational risk factors: Findings for oncogenic viruses exposure and other occupational exposures. Environ Res 167: 393-410.

4. Buehring GC, Philpott SM, Choi KY (2003) Humans have antibodies reactive with Bovine Leukemia Virus. AIDS Res Hum Retroviruses 19(12):1105-1113.

5. Buehring GC, DeLaney A, Shen H, David LC, Niema R, et al. (2019) Bovine Leukemia Virus discovered in human blood. BMC Infect Dis 19(1): 297.

6. Schwingel D, Andreolla AP, Erpen LMS, Frandoloso R, Kreutz LC (2019) Bovine Leukemia Virus DNA associated with breast cancer in women from South Brazil. Sci Rep 9(1): 2949.

7. Lehrer S, Rheinstein PH (2019) Mouse mammary tumor viral env sequences are not present in the human genome but are present in breast tumors and normal breast tissues. Virus Res 266: 43-47.

8. Yizhak K, Aguet F, Kim J, Hess JM, Kübler K, et al. (2019) RNA sequence analysis reveals macroscopic somatic clonal expansion across normal tissues. Science 364(6444) pii: eaaw0726.

For possible submissions Click below: 